\title{
殺虫性有機リン化合物の立体化学に関する研究
}

\author{
吳 少 勇*, 平島明法 \\ 九州大学農学部農芸化学科農薬講座
}

\section{Stereochemistry of Insecticidal Organophosphorus Compounds}

\author{
Shao-Yong Wu* and Akinori Hirashima \\ Department of Agricultural Chemistry, \\ Kyushu University, Fukuoka 812, Japan
}

\begin{abstract}
Aryl methyl phosphorochloridothionates (AMPC) were found as two-step phosphorylation reagents. The 4-nitrophenyl and 2,6-dichloro-4-methylphenyl derivatives (MNPC and CMPC) were resolved into optically active enantiomers to synthesize optical isomers of ten kinds of insecticidal 1,3,2-oxazaphospholidine 2-sulfides and two kinds of 1,3,2-benzodioxaphosphorin 2-sulfides, including the commercial insecticide salithion. Of all the 4-substituted oxazaphospholidines, $(S)_{\mathrm{c}}(R)_{\mathrm{p}}$ isomers showed the highest insecticidal activity, followed by $(S)_{\mathrm{c}}(S)_{\mathrm{p}}>(R)_{\mathrm{c}}(R)_{\mathrm{p}}>(R)_{\mathrm{c}}(S)_{\mathrm{p}}$ and for 5-phenyl oxazaphospholidine, $(R)_{\mathrm{c}}(R)_{\mathrm{p}}>(R)_{\mathrm{c}}(S)_{\mathrm{p}}>$ $(S)_{\mathrm{c}}(R)_{\mathrm{p}}>(S)_{\mathrm{c}}(S)_{\mathrm{p}} . \quad(S)_{\mathrm{c}}$-Configuration in the 4-substituted oxazaphospholidine and $(R)_{\mathrm{c}}$ in the 5-phenyl derivative appear essential for a high insecticidal activity, consistent with Land D-configuration of natural amino acids and octopamine, respectively. In the benzodioxaphosphorins, the $(S)_{\mathrm{p}}$ configuration was favorable for a high insecticidal activity. The oxidative desulfurization of salithion by MCPBA produced an isomerized product (S-benzyl salithion) with racemization as well as the expected salioxon with retention of configuration. Bis(4-chloro-2-ethylphenyl) phenylphosphonate was metabolically transformed into the corresponding cyclic (predominantly cis) ester in houseflies in vivo. The $(+)$-enantiomer of sulprofos, resolved by acid-catalyzed ethanolysis of the diastereoisomer of proline derivative, was more toxic than (-)-enantiomer to houseflies. The chiral specificity was reversed relative to potency as inhibitor of housefly head AChE activity. Most of phosphorothiolates were activated to more potent inhibitors of electric eel $\mathrm{AChE}$ on coincubation with a mouse liver microsomal oxidase system. (-)-Sulprofos oxon sulfone was the exception, undergoing stereoselective detoxification when unwashed microsomes were used. Isofenphos was bioactivated by MFOs in two steps that ultimately gave $N$-desisopropyl isofenphos oxon, a product with 2300 -fold greater inhibitory potency than isofenphos oxon toward housefly head AChE. The isofenphos isomers, resolved on a chiral HPLC column, had the same stereospecificity for MFO-activated anti-AChE activity and toxicity to houseflies, possibly due to enantiomeric differences in $\mathrm{AChE}$ inhibitory potency.
\end{abstract}

\section{は じめに}

現在数多くの有機リン酸エステルが農薬として使われ

* 現在：北京農業大学応用化学研究所

Present address: Institute of Applied Chemistry, Beijing Agricultural University, Beijing, China
ている. 環状有機リン酸エステルはあまり知られていな いが，当研究室において六員環状有機リン酸エステルの サリチオン1) が発見され，実用殺虫戍として開発されて いる. また，著者らはアミノ酸由来五員環状ホスホロア ミド酸エステルの ${ }^{i} \mathrm{BMOS}^{2)}$ やオクトパミン類似骨格 を持っ 5-PMOS ${ }^{3)}$ に強い殺虫活性を見いだした(Fig. 1). 
<smiles>CO[P@]1(=S)OCc2ccccc2O1</smiles>

Salithion<smiles>CO[P@]1(=S)N[C@@](C)(CC(C)C)CO1</smiles>

i BMOS<smiles>CO[P@]1(=S)NCC(c2ccccc2)O1</smiles>

Fig. 1 Chemical structures of bioactive cyclic organophosphorus compounds.

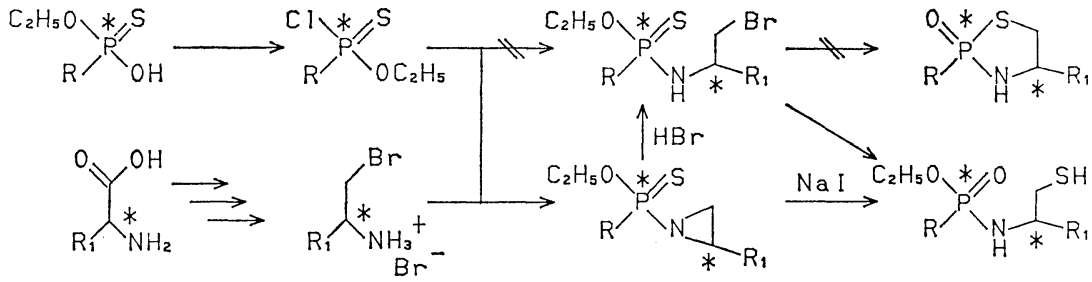

Fig. 2 An attempt at thiazaphospholidine synthesis and formation of aziridinylphosphinothionates.

一方, 光学異性体の立体配置と生物活性の関係を明らか にすることは, 殺虫作用の機構を解明するうえで非常に 重要であり，近年盛んに研究されている4). そこで，上 述の環状有機リン化合物の光学異性体を合成し, 立体配 置と生物活性の関係を調べるために, 立体特異的合成法 を検討した。また，有機リン化合物の硫黄や窒素原子は， 生体内で酸化され活性化あるいは解毒化されることが知 られている. 光学異性体間の殺虫力の差は, この酸化反 応の立体特異性による場合も考えられる，そこで，環状 有機リン酸エステルの化学酸化, 非環状有機リソ酸エス テル・ホスホロアミド酸エステルのミクロゾーム酸化・ イエバェ体内での代謝に打ける立体特異性も検討した. 本論文では，これらの研究の経緯を説明する.

\section{不斉二段階リン酸化剂の発見}

アミノ酸由来五員環状ホスホロアミド酸エステル類の 構造と殺虫活性の関係を検討する過程で5), thiazaphospholidine に高い殺虫活性を見いだしたので2), 光学活性 ethyl phosphonochloridothionate そ, アミノ酸より誘導 した $\beta$-bromoethylamine より, 光学活性 thiazaphospholidine の合成を試みた。その際，予測しなかったアジリ ジン誘導体を生成し, さらに $\mathrm{P}=\mathrm{S}$ の分子内アルキル化 に続く加水分解によって P-S 結合が開裂する興味ある 反応を見いだしたが，目的物は合成できなかっだ)(Fig， 2). 二段階リン酸化剂としては, サリチオンの異性体 MTBO がすでに知られており， cyclic AMP 等の合成に 応用されている7). しかし，この方法は光学活性体の合 成には適当ではない，そこで，さらに種々の立体特異的

$$
\text { Aminoal cohols }
$$

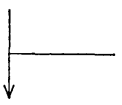<smiles>[R]C1O[P@](C)(=S)N[C@H]1C</smiles>

Oxazaphospholidines

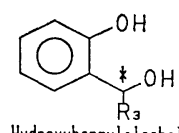

Hydroxybenzylalcohols

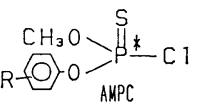

ICUPC: $\mathrm{R}=2,6-\mathrm{Cl}_{2}-4-\mathrm{HeI}_{\mathrm{e}}$

(NNPC: $\mathrm{R}=4-\mathrm{NO}_{2}$ )
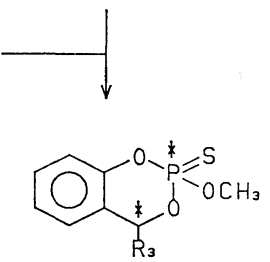

Benzodioxaphosphorins
Fig. 3 Syntheses of optically active oxazaphospholidines and benzodioxaphosphorins using AMPC chiral two-step phosphorylation reagents.

合成法を検討した結果, クロロチオリン酸アリールエス テル (AMPC) (Fig. 3) が，二段階リン酸化剂として有 用であることを見いだした ${ }^{8)}$. アリール置換基により反 応性は異なった $\left.{ }^{9 \sim 11}\right)\left[k\left(\mathrm{M}^{-1} \cdot \min ^{-1}\right) ; \mathrm{R}=4-\mathrm{NO}_{2}>3-\mathrm{Me}-\right.$ $\left.4-\mathrm{NO}_{2}>4-\mathrm{Ac}>4-\mathrm{Ph}>2,6-\mathrm{Cl}_{2}-4-\mathrm{Me}>4-\mathrm{Cl}>\mathrm{H}\right]$. その中 で,メチルパラチオンと殺菌剤トルクロホスメチルから 誘導した MNPC と CMPC をおのおの光学分割し, 光学 活性環状有機リン酸エステル類の合成に用いた。

\section{Methyl p-nitrophenyl phosphorochloridothion- ate (MNPC)}

メチルパラチオンを $\mathrm{CH}_{3} \mathrm{CN}$ か $\mathrm{CH}_{3} \mathrm{OH}$ 中, strychnine と反応させて得られる methostrychnium 塩を光学分割 した後 $\left(\mathrm{CH}_{3} \mathrm{CN}\right.$ からは十体, $\mathrm{CH}_{3} \mathrm{OH}$ からは一体)，硝 酸銀で（一）と（十）銀塩とし，五塩化リンと反応させ 


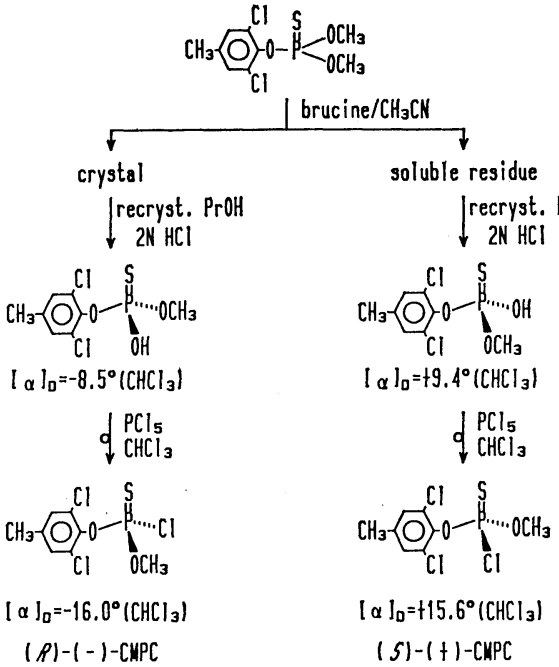

Fig. 4 Preparation of optically active CMPC.

\section{（+）と(一) MNPCを打の打の得た ${ }^{8)}$.}

2. 2, 6-Dichloro-4-methylphenyl methyl phosphorochloridothionate (CMPC) (Fig. 4)

トリクロホスメチルを $\mathrm{CH}_{3} \mathrm{CN}$ 中 brucine と反応する と, 脱メチル体の methobrucinium 塩を与えた。 これを 光学分割しおの打のの塩を滥酸で遊離, 酸にした後, 五 塩化リンと反応させ, $(+),(-)$ 酸から $(+),(-)$ CMPC を扮の扮の得た ${ }^{9}$.

\section{3. 光学純度・立体配置の決定 (Fig. 5)}

光学活性 AMPC (Fig. 5 では CMPCを例示) をおの おの 2 等量の $(S)$ - $\alpha$-phenylethylamine (PEA) と $\mathrm{CHCl}_{3}$ 中で反応させ，そのジアステレオマーに導いた。 $(S)$ PEA 部分のベンゼン環とAMPCのメトキシ基の立体 関係により,メトキシプロトンの ${ }^{1} \mathrm{H}-\mathrm{NMR}$ 化学シフト
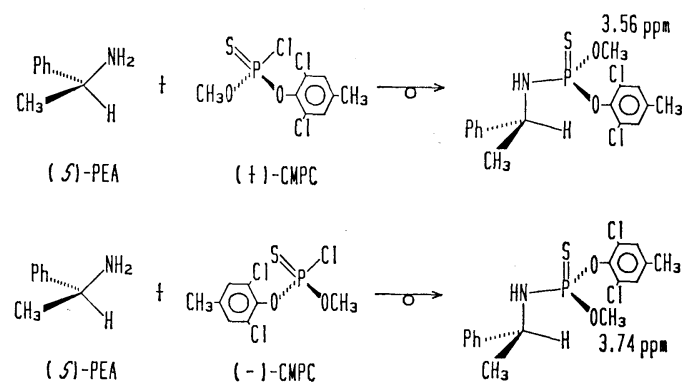

Fig. $5 \quad{ }^{1} \mathrm{H}-\mathrm{NMR}$ spectra of diastereomers derived from CMPC and $(S)$-PEA.

はかなり異なった。すなわち、ベンゼン環がメトキシ基 と同じ側にある場合には，メトキシプロトンはベンゼン 環の遮弊効果により高磁場にシフトする ${ }^{6,8}$. AMPC と $(S)$-PEA の反応は立体反転で起こるので9)，(+), (-) AMPC の立体配置は打の扮の $(S),(R)$ と決定した。 たこの反応は, 立体特異的に 1 種のジアステレオマーを 与えたことより（十)，(）MNPC の光学純度は打の扔 の $100 \%$ と考光られた.

\section{光学活性環状有機リン酸エステル類の 合成と殺虫活性}

ロイシン・オクトパミン等の生理活性アミノ酸・アミ ン類から 10 種の五員環状ホスホロアミド酸エステルと, サリチオン等 2 種の六員環状有機リン酸エステルの全光 学異性体を CMPC を用いて合成した ${ }^{12,13)}$. 前者と置換 サリチオン (CMMBS) ではほぼ純粋な光学異性体が得 られたが，サリチオンの場合には若干のラセミ化が起き た (e.e.79〜84\%) (Table 1). とこで，小泉らにより開発 されたプロリン誘導体法 ${ }^{14)}$ を応用して, 光学純度 98

Table 1 Spectral data of optically active 1,3,2-benzodioxaphosphorin 2-sulfides (BS).

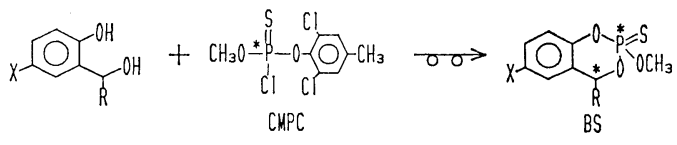

\begin{tabular}{cllccc}
\hline BS & $\mathrm{R}$ & $\mathrm{X}$ & $\begin{array}{c}{ }^{13} \mathrm{P}-\mathrm{NMR} \\
(\delta \mathrm{ppm})\end{array}$ & $\begin{array}{c}{[\alpha]_{\mathrm{D}}\left({ }^{\circ}\right)} \\
\left(c \text { in } \mathrm{CH}_{3} \mathrm{CN}\right)\end{array}$ & $\begin{array}{c}\text { e.e. } \\
(\%)\end{array}$ \\
\hline$(S)$-Salithion & $\mathrm{H}$ & $\mathrm{H}$ & 55.9 & $-7.8(0.32)$ & 84 \\
$(R)-$ Salithion & $\mathrm{H}$ & $\mathrm{H}$ & 55.9 & $+7.0(0.40)$ & 79 \\
$(R)_{\mathrm{c}}(S)_{\mathrm{p}}-\mathrm{CMMBS}$ & $\mathrm{CH}_{3}$ & $\mathrm{Cl}$ & 60.6 & $+19.4(0.57)$ & \\
$(S)_{\mathrm{c}}(R)_{\mathrm{p}}$-CMMBS & $\mathrm{CH}_{3}$ & $\mathrm{Cl}$ & 60.6 & $-19.2(0.26)$ & \\
$(S)_{\mathrm{c}}(S)_{\mathrm{p}}-\mathrm{CMMBS}$ & $\mathrm{CH}_{3}$ & $\mathrm{Cl}$ & 58.9 & $-25.0(0.48)$ & 97 \\
$(R)_{\mathrm{c}}(R)_{\mathrm{p}}$-CMMBS & $\mathrm{CH}_{3}$ & $\mathrm{Cl}$ & 58.9 & $+24.6(0.41)$ & 97 \\
\hline
\end{tabular}




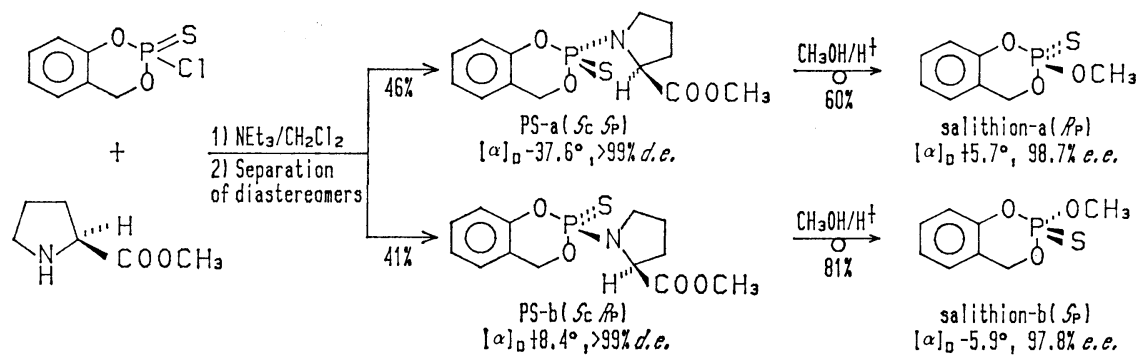

Fig. 6 Synthesis of optically active salithion.

99\%のサリチオン両鏡像体を得た ${ }^{15)}$. 核磁気共鳴スペ クトル $(\mathrm{NMR})$ 分析・X 線結晶解析でそれらの立体配 置を決定し，反応機構を明らかにした(Fig. 6).

\section{1. 光学活性アミノアルコールの合成と CMPC との} 反応

光学活性アミノ酸のエステルを水素化ホウ素ナトリウ 厶 $\left(\mathrm{NaBH}_{4}\right)$ で還元して, 光学活性アミノアルコールを 得た ${ }^{2)}$. 光学活性フェニルェタノールアミン (HPEA) は, 光学活性マンデル酸よりメチルエステルを経てアミ ドへ導き，水素化リチウムアルミニウム $(\mathrm{LAH})$ で還元 して得た ${ }^{16)}$. このようにして得たアミノアルコール 2 等 量と $\mathrm{CMPC}$ を $\mathrm{CHCl}_{3}$ 中, 室温で 10〜24 時間攪汼する と, 目的の環状化合物が約 $60 \%$ の収率で得られた。この 反応を, CMPCよりも第 2 脱離基（アリールオキシ）の 反応性が低い $\mathrm{PMPC}(\mathrm{R}=\mathrm{H})$ を用いて ${ }^{31} \mathrm{P}-\mathrm{NMR}$ でモ二 ターすると, 中間体アミド $\mathrm{P}-\mathrm{NOl}$ の存在が確認できた (Fig. 7).すなわち, AMPC のクロルがアミノアルコー ルのアミノ基で最初に置換され, 次に水酸基が分子内で アリールオキシと置換して閉環するものと考えられる (Fig. 7).

\section{2. 光学純度 ・立体配置の決定}

五員環状ホスホロアミド酸エステルの立体配置は, ${ }^{1} \mathrm{H}-\mathrm{NMR}$ によって決定した。すなわち， $\mathrm{P}=\mathrm{S}$ とシス位 にある 4,5 位置換基のプロトンは脱遮弊効果により低磁

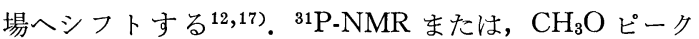
の ${ }^{1} \mathrm{H}-\mathrm{NMR}(400 \mathrm{MHz})$ 積算值より求めた光学純度は, 98〜99\% と非常に高かった. サリチオンに関しては, CHIRALPAK OT (十) $\left(\mathrm{CH}_{3} \mathrm{OH}\right)$ または, CHIRALCEL $\mathrm{OB}$ (ヘキサン: $i \mathrm{PrOH}=10: 1)$ を用いた高速液体クロマ トグラフ (HPLC) により直接分析し, 光学純度を決定 した. プロリン誘導体 (PS) の立体配置は, 同様に ${ }^{1} \mathrm{H}$ NMR で推定し(Fig. 8), (+) 体 (PS-b) のX線結晶解 析により確認した。モデル実験より硫酸触媒メタノリシ スは立体反転を伴うことがわかり, サリチオンの立体配 置を決定できた ${ }^{15)}$.

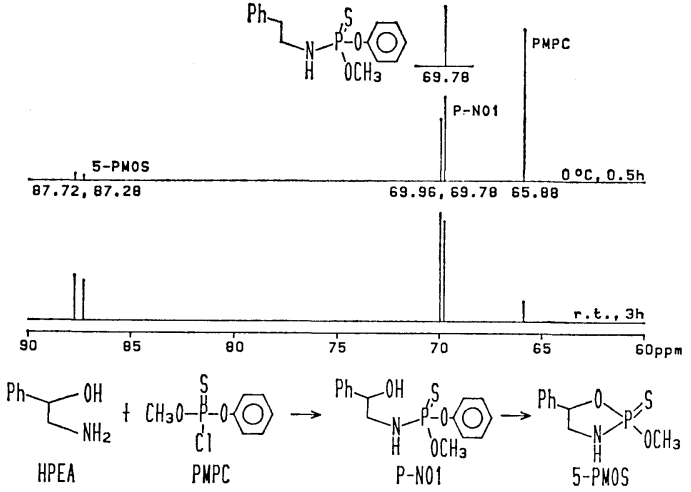

Fig. $7{ }^{31} \mathrm{P}-\mathrm{NMR}$ Monitoring of the reaction between phenylethanolamine (PEA) and PMPC. Signals at 69.96 and $69.78 \mathrm{ppm}$ are thought to be from the intermediate P-NO1.



$P S-a(S c S p)$

$\mathrm{Ha}_{\mathrm{a}}: 4.52 \mathrm{ppm}$

$\mathrm{Hb}: 5.14 \mathrm{ppm}, J \mathrm{PH}_{\mathrm{b}}=24.8 \mathrm{~Hz}$

$\mathrm{Hc}_{\mathrm{c}}: 5.59 \mathrm{ppm}, \mathrm{JPH}_{\mathrm{c}}=6.8 \mathrm{~Hz}$

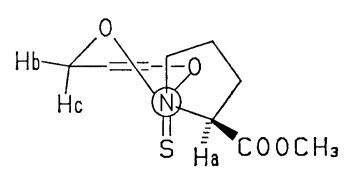

$P S-b(S c R p)$

Ha: $4.59 \mathrm{ppm}$ $\mathrm{Hb}: 5.18 \mathrm{ppm}, \mathrm{JPH}_{\mathrm{b}}=25.6 \mathrm{~Hz}$ $\mathrm{Hc}: 5.62 \mathrm{ppm}, \mathrm{JPH}_{c}=6.6 \mathrm{~Hz}$
Fig. 8 Proposed stable conformation of PS-a and PS-b based on ${ }^{1} \mathrm{H}-\mathrm{NMR}$ analysis.

\section{3. 殺虫活性 (Table 2)}

イエバェに対する殺虫活性は 4 位置換五員環状ホス ホロアミド酸エステルでは, $(S)_{\mathrm{c}}(R)_{\mathrm{p}}>(S)_{\mathrm{c}}(S)_{\mathrm{p}}>$ $(R)_{\mathrm{c}}(R)_{\mathrm{p}}>(R)_{\mathrm{c}}(S)_{\mathrm{p}}$ の順で ${ }^{18)}($ Fig. 9), 5-PMOS では $(R)_{\mathrm{c}}(R)_{\mathrm{p}}>(R)_{\mathrm{c}}(S)_{\mathrm{p}}>(S)_{\mathrm{c}}(R)_{\mathrm{p}}>(S)_{\mathrm{c}}(S)_{\mathrm{p}}$ となり ${ }^{19)}$, リン原子については $(R)$, 不斉炭素ではアミノ酸やオク トパミンの天然型立体配置が，最も高い殺虫活性を示し 
Table 2 Insecticidal activity of optically active OS and BS against susceptible and resistant houseflies.

\begin{tabular}{|c|c|c|c|c|}
\hline \multirow{2}{*}{ Compounds } & \multicolumn{3}{|c|}{$\mathrm{LD}_{50}(\mu \mathrm{g} / \mathrm{fly})$} & \multirow{2}{*}{$\mathrm{R} / \mathrm{S}$} \\
\hline & SRS & $3-\mathrm{Y}$ & $3-Y_{F}$ & \\
\hline \multicolumn{5}{|l|}{${ }^{i} \mathrm{PMOS}$} \\
\hline$(S)_{\mathrm{c}}(R)_{\mathrm{p}}(c i s)$ & 0.09 & 1.44 & & 16.0 \\
\hline$(S)_{\mathrm{c}}(S)_{\mathrm{p}}($ trans $)$ & 0.11 & 1.38 & & 12.5 \\
\hline$(R)_{\mathrm{c}}(R)_{\mathrm{p}}($ trans $)$ & 0.20 & 2.15 & & 10.8 \\
\hline$(R)_{\mathrm{c}}(S)_{\mathrm{p}}(c i s)$ & 0.22 & 2.54 & & 11.5 \\
\hline \multicolumn{5}{|l|}{ 5-PMOS } \\
\hline$(R)_{\mathrm{c}}(R)_{\mathrm{p}}(c i s)$ & 0.02 & & 0.09 & 4.5 \\
\hline$(R)_{\mathrm{c}}(S)_{\mathrm{p}}($ trans $)$ & 0.06 & & 0.33 & 5.5 \\
\hline$(S)_{\mathrm{c}}(R)_{\mathrm{p}}($ trans $)$ & 0.09 & & 0.97 & 10.8 \\
\hline$(S)_{\mathrm{c}}(S)_{\mathrm{p}}(c i s)$ & 0.13 & & 2.47 & 19.0 \\
\hline \multicolumn{5}{|l|}{ Salithion } \\
\hline Racemic & 0.06 & & 0.62 & 10.3 \\
\hline$(S)_{\mathrm{p}}-(-), 84 \%$ e.e. & 0.05 & 0.30 & & 6.0 \\
\hline $98 \%$ e.e. & 0.05 & & 0.40 & 8.0 \\
\hline$(R)_{\mathrm{p}}-(+), 79 \%$ e.e. & 0.07 & 0.42 & & 6.0 \\
\hline $99 \%$ e.e. & 0.12 & & 0.91 & 7.6 \\
\hline \multicolumn{5}{|l|}{$\mathrm{EPPP}^{\mathrm{a}}$} \\
\hline$(R)_{\mathrm{p}}$ & 0.05 & 0.56 & & 11.2 \\
\hline$(S)_{\mathrm{p}}$ & 0.09 & 10.00 & & 111 \\
\hline Fenitrothion & 0.07 & 18.16 & $>200$ & $259,>2857$ \\
\hline Malathion & 0.67 & $>200$ & $>200$ & $>299,>299$ \\
\hline
\end{tabular}

a) $O$-Ethyl $S$-propargyl phenylphosphonothiolate.

た.サリチオン類のリン原子については, $(S)$ 配置が $(R)$ に優った。環状有機リン酸エステル類は, EPPP. フェニトロチオン・マラチオン等の非環状有機リン酸エ ステルに比べて, 感受性イエバェ (SRS) ばかりでなく, 他の有機 リン剂抵抗性イエバェ (3-Y, 3-Y $\left.\mathrm{F}_{\mathrm{F}}\right)$ に対して も優れた効果を示した.

\section{サリチオン類の反応}

1. MCPBA によるサリチオン類の異性化反応（Fig. 10)

$\mathrm{P}=\mathrm{S}$ を持つすべての有機リン化合物は, in vivo, in vitro でミクロゾーム酸化酵素系 $(\mathrm{MFO})$ により, $\mathrm{P}=\mathrm{O}$ に変換されることが知られている ${ }^{20)}$. 有機チオリン酸エ ステルの酸化的代謝の研究において, MFO の代用として 化学的酸化モデル系にメタクロロ過安息香酸 (MCPBA) がよく使われるが，必ずしもすべての場合に適している わけではない21)。サリチオン類は, MCPBA で酸化する と予想産物のサリオキンンのほかに, 異性化した $S$-ベン ジルサリオキンンを与えた ${ }^{22)}$. 前者では立体保持, 後者 はラセミ化し，これらの産物は，オキシナート中間体か
ら由来すると考元られた，異性化反応は，溶媒の影響を 受け $\mathrm{CHCl}_{3}(60 \%), \mathrm{CH}_{2} \mathrm{Cl}_{2}$ ・酶酸エチル $(\sim 45 \%)$ 中 ではよく起こるが, ベンゼン (14\%), トルェン (19\%), テトラヒドロフラン $(11 \%)$ では少なく， $N, N$-ジメチル ホルムフミド (DMF) 中では起きなかった。 また, ラッ 卜肝臟 MFO を用いた反応系でもサリオキソンの生成だ けで, 異性化反応は認められなかった。

2. フェニルホスホン酸ビス-o-エチルフェニルの代 謝閉環反応 (Fig. 11)

Tri-o-tolyl phosphate(TOCP) は, メチル基の水酸化 とそれに引き続く閉環によりサリゲニン環状リン酸エス テルになることがすでに報告されている ${ }^{23)}$. TOCP と同 様な生物活性を示す triaryl phosphate は, 通常少なくと も一つの一級アルキル基をオルト位に持つので, 生体内 で活性化され，サリゲニン環状リン酸エステルに代謝さ れることが予測された. そこで, フェニルホスホン酸ビ スーーーエチルフェニル (BEPP) をモデル化合物として選 び,イエバエ体内での代謝を検討したところ，p-hydroxyphenoxy 体 (BEPP-OH) のほかに環状代謝物 (MPBO) のシス体が立体選択的に生成することがわかった ${ }^{24)}$. 




Fig. 9 Structure-insecticidal activity relationship of oxazaphospholidines.

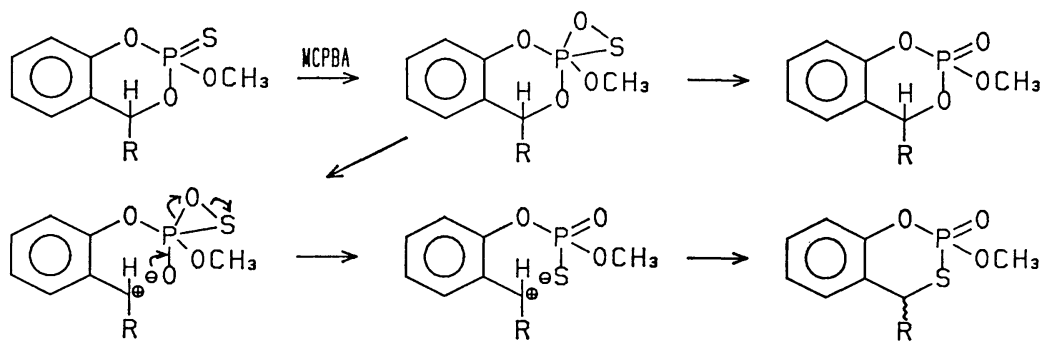

Fig. 10 Proposed mechanism for the thiono-thiolo isomerization by MCPBA.

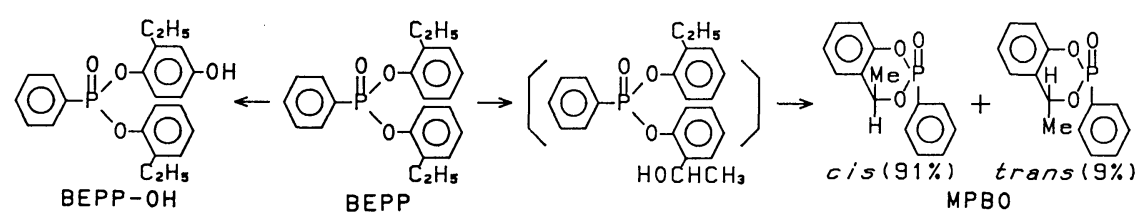

Fig. 11 Metabolic hydroxylation and cyclization of bis(o-ethylphenyl) phenylphosphonate (BEPP). 


\section{光学活性非環状リン酸エステル}

\section{1. スルプロホス関連化合物の光学分割と立体特異性}

$S$-Propyl phosphorothiolate は, 他の有機リン殺虫剤 抵抗性の害虫に卓効を示すことが知られている25).プロ フェノホス [O-(4-bromo-2-chlorophenyl) $O$-ethyl $S$-propyl phosphorothiolate] は，おそらくチオレート酸化に より生体内で活性化されるが26)，その $S$-oxide は遷移中 間体である27). ミクロゾーム酸化による活性化は，光学 異性体間で立体特異的で，(一)体は 34 倍活性化，(+)体 は $1 / 2$ に解毒化され ${ }^{26)}$ ，代謝や作用機作における立体化 学の重要性を示唆している ${ }^{28)}$. 綿・野菜の害虫防除に用 いられているスルプロホス [O-ethyl O-[4-(methylthio)phenyl] $S$-propyl phosphorodithioate] は分子内に 3 種の 異なった硫黄原子を持ち，その硫黄原子の酸化により生 体内で活性化される ${ }^{29)}$. そこで，生体内活性化における 光学異性体間の立体特異性を検討するために，スルプロ ホスとその関連化合物多数を前述のプロリン誘導体法に より光学分割した ${ }^{30)}$. イエバエに対し（十）スルプロ ホスオキソン・(一) プロフェノホスが，おのおの（一) スルプロホスオキソン・(十) プロフェノホスより強い 殺虫力を示したが，そのアセチルコリンエステラーゼ (AChE) 阻害活性は逆転した (Table 3). 多くの phosphorothiolate は, MFO で活性化され強い AChE 阻害活 性を示したが，(一）スルプロホスオキソンスルホンと （十）プロフェノホスは例外で，その AChE 阻害活性は 低下した，さらに精製した MFOを用いると，本来弱い $\mathrm{AChE}$ 阻害剤である (一) プロフェノホスは酸化活性化 され，強い $\mathrm{AChE}$ 阻害剤である（十）プロフェノホス は, 可溶性画分の存在により解毒化された ${ }^{30)}$.

\section{2. イソフェンホスの酸化的 $N$-脱アルキル化と脱 オウによる活性化}

イソフェンホス [O-ethyl O-[2-(isopropoxycarbonyl)phenyl] isopropylphosphoramidothionate] は代謝的にさ らに強い AChE 阻害剤に活性化されるが，その機構は いくつか考えられる. そこで，イソフェンホスの生体内 活性化の機構を検討し，さらに光学異性が及ぼす影響を 明らかにするために，[リング-14C] イソフェンホスを Sumipax OA-4000を用いた HPLC（へキサン）で光学 分割した ${ }^{31)}$ イイソフェンホスは，MFOにより脱硫黄と $N$-脱イソプロピルの二段階で活性化され，最終的にイソ フェンホスオキソンよりも 2300 倍強い AChE 阻害剤で ある $N$-脱イソプロピルイソフェンホスオキソンを与え た。この反応は，チトクローム P-450 の作用で，おそら く $\alpha$ 炭素の酸化により $N$-脱アルキル化するものであ
Table 3 Biological activity of the enantiomers of sulprofos oxon, sulprofos oxon sulfone and profenofos against houseflies.



\begin{tabular}{|c|c|c|c|c|}
\hline & $\mathrm{R}$ & & $\begin{array}{c}\mathrm{I}_{50} \\
(\mu \mathrm{M})\end{array}$ & $\begin{array}{c}\mathrm{LD}_{50} \\
(\mu \mathrm{g} / \mathrm{g})\end{array}$ \\
\hline \multirow[t]{3}{*}{ Sulprofos oxon } & $4-\mathrm{SCH}_{3}$ & $(+)$ & 12 & 4 \\
\hline & & $(-)$ & 5 & 10 \\
\hline & $\mathrm{O}$ & & & \\
\hline \multirow{2}{*}{$\begin{array}{l}\text { Sulprofos oxon } \\
\text { sulfone }\end{array}$} & $\uparrow$ & $(+)$ & 0.0069 & 1 \\
\hline & $\begin{array}{c}4-\mathrm{SCH}_{3} \\
\downarrow \\
\stackrel{\mathrm{O}}{ }\end{array}$ & $(-)$ & 0.0009 & 20 \\
\hline \multirow[t]{2}{*}{ Profenofos } & 2-Cl, & $(-)$ & 0.19 & 4 \\
\hline & $4-\mathrm{Br}$ & $(+)$ & 0.11 & 10 \\
\hline
\end{tabular}

Table 4 Potency of isofenphos and its resolved enantiomers as injected toxicants for houseflies and as inhibitors of electric eel AChE.

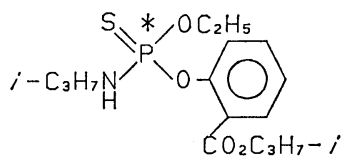

\begin{tabular}{ccccc}
\hline & & $(+)$ & $(-)$ & $( \pm)$ \\
\hline None & 0.47 & 8.4 & 1.3 \\
$\mathrm{LD}_{50}(\mu \mathrm{g} / \mathrm{g})$ & $+\mathrm{PB}$ & 0.36 & 8.8 & 1.3 \\
$+\mathrm{PSCP}$ & 0.12 & 3.7 & 0.26 \\
$\mathrm{AChE}($ inhib., \%) & & & \\
$+\mathrm{MFO}$ & 3 & 0 & -4 \\
$+\mathrm{MFO}+\mathrm{NADPH}$ & 72 & 5 & 60
\end{tabular}

a) Isofenphos at $1 \mu \mathrm{M}$.

り, AChE 阻害活性中間体の生成は認められない。イエ バェに対する殺虫活性は（十）体のほうが（一）体より も強く，さらにミクロゾーム酸化系で（十）体が著しく 活性化され，高い AChE 阻害活性を示した (Table 4)。 イエバェに拈ける代謝では，両鏡像体間に著しい差は認 められなかった. したがって, 両鏡像体間の殺虫力の差 は, その酸化活性体 (N-脱イソプロピルイソフェンホス オキソン) の AChE に対する親和性の相違によるもの と思われる。

\section{おわりに}

光学活性環状有機リン酸エステルは, 農薬として使用 されているトルクロフォスメチルやメチルパラチオンよ 
り得た二段階リン酸化剂（AMPC）を用いて，非常に高 い光学収率で合成できた。この方法は, AMPCのクロル とアリールオキシの脱離性の差と, アミノアルコールや サリゲニンおのおのの二つの官能基の反応性の差に注目 して開発した方法であるが，ほかのさまざまな光学活性 有機リン酸エステルの合成にも応用できると考えられ る.

環状・非環状有機リン酸エステルの立体配置と殺虫活 性の関係を論じてきたが，殺虫活性は，薬物の昆虫体内 への浸透・体内での活性化・解毒化等, さまざまな要因 が関与しているため, 殺虫活性の光学異性体間の立体特 異性を一概に論ずることはなお困難である. 今後, より 詳細な検討が必要と思われるが，本研究がその一助にな れば幸いである。

本研究を行なうに当たり，ご指導ご鞭撻を賜りました 九州大学農学部の江藤守総教授とカリフォルニア大バー クレー校の Casida 教授に心よりお礼を申し上げます. また, 谷口栄二助教授・桑野栄一博士 ・武谷立子技官 (九州大学農学部), 住友化学工業(株), 農業環境技術研 究所の諸氏を初めとする多くの共同研究者に感謝いたし ます.

\section{引用 文 献}

1) M. Eto: Rev. Plant Prot. Res. 9, 1 (1976)

2) 江藤守総 - 平島明法 - 多和田真吉 - 大島康平：日 化誌 5, 705 (1981)

3) 江藤守総 - 吳 少勇: 特願昭 62 申請中

4) H. Ohkawa: “Insecticide Mode of Action," ed. by J. R. Coats, Academic Press, New York, p. 163,1982

5) H. Yoshikawa, M. Yasuda, A. Hirashima, K. Oshima \& M. Eto: Agric. Biol. Chem. 44, 1447 (1980)

6) A. Hirashima \& M. Eto: Agric. Biol. Chem. 47, 829 (1983)

7) M.-Y. Eto, M. Iio, Y. Kobayashi, H. Omura \& M. Eto: Agric. Biol. Chem. 38, 2081 (1974)

8) A. Hirashima \& M. Eto: Agric. Biol. Chem. 47, 2831 (1983)

9) S.-Y. Wu \& M. Eto: Agric. Biol. Chem. 48, 3071 (1984)

10) 呉 少勇 - 平島明法 - 江藤守総：九大中央分析七 ソター報告 2, 49 (1987)

11) S.-Y. Wu \& M. Eto: Abstr. 3rd Int. Kyoto Conf. New Aspects Org. Chem., Kyoto, 19-L-9, p. 127, 1985

12) S.-Y. Wu, A. Hirashima, E. Kuwano \& M. Eto: Agric. Biol. Chem. 51, 537 (1987)

13) A. Hirashima, S.-Y. Wu \& M. Eto: Abstr. 1st
Int. Conf. Heteroatom Chem., Kobe, PS3017, p. 210,1987

14) T. Koizumi, Y. Kobayashi \& E. Yoshii: J. Org. Chem. 42, 3459 (1977)

15) 呉 少勇 - 平島明法 $\cdot$ 江藤守総：第 13 回日本農 薬学会大会講演要旨集, p. 107, 1988

16) P. Pratesi \& M. Grassi: Farmaco, Ed. Sci. 8, 86 (1953)

17) D. Z. Denney, G. Y. Chen \& D. B. Denney: $J$. Am. Chem. Soc. 91, 6838 (1969)

18) S.-Y. Wu, R. Takeya, M. Eto \& C. Tomizawa: J. Pesticide Sci. 12, 221 (1987)

19) 呉 少勇 - 平島明法 - 江藤守総： 昭和 63 年度農 芸化学会大会講演要旨集, p. 350, 1988

20) M. Eto: "Organophosphorus Pesticide: Organic and Biological Chemistry," CRC Press, Cleaveland, p. 158, 1974

21) E. M. Bellet \& J. E. Casida: J. Agric. Food Chem. 22, 207 (1974)

22) S.-Y. Wu \& M. Eto: J. Pesticide Sci. 12, 95 (1987)

23) M. Eto, J. E. Casida \& T. Eto: Biochem. Pharmacol. 11, 337 (1962)

24) S.-Y. Wu, S. Ito \& M. Eto: Agric. Biol. Chem. 51, 2935 (1987)

25) A. Kudamatsu, A. Iyatomi, A. Hayashi \& R. Kano: Jpn. J. Sanit. Zool. 29, 317 (1978)

26) K. D. Wing, A. H. Glickman \& J. E. Casida: Science 219, 63 (1983)

27) Y. Segall \& J. E. Casida: Tetrahedron Lett. 23, 139 (1982)

28) J. E. Casida: "Cholinesterase: Fundamental and Applied Aspects," ed. by M. Brzin, E. A. Barnard \& D. Sket, de Gruyter, New York, p. 427,1984

29) D. L. Bull \& G. W. Ivie: J. Agric. Food Chem. 24, 143 (1976)

30) A. Hirashima, H. Leader, I. Holden \& J. E. Casida: J. Agric. Food Chem. 32, 1302 (1984)

31) G. Gorder, O. Kirino, A. Hirashima \& J. E. Casida: J. Agric. Food Chem. 34, 941 (1986) 